\title{
ІМПЛЕМЕНТАЦІЯ СТАНДАРТІВ БЕЗПЕКИ ТА ПРОФЕСІЙНОГО НАВЧАННЯ ВСЕСВІТНЬОЇ МИТНОЇ ОРГАНІЗАЦІї: УКРАЇНСЬКИЙ ДОСВІД
}

\begin{abstract}
На прикладі украӥнського досвіду у статті висвітлено проблемні моменти впровадження міжнародних стандартів у галузі транзитних перевезень, які стосуються стандартів безпеки та спрощення світової торгівлі SAFE, а також стандартів Всесвітньої митної організації щңодо підготовки й підвищення кваліфікації фахівців у сфері зовнішньоекономічної діяльності.

Ключові слова: рамкові стандарти безпеки SAFE, міжнародні професійні стандарти, підготовка, транзитні перевезення.
\end{abstract}

На примере украинского опыта в статье освещены проблемные моменты внедрения международных стандартов в сфере транзитных перевозок, которые касаются стандартов безопасности и упрощения мировой торговли SAFE, а также подготовки и повышения квалификачии спечиалистов в сфере внешнеэкономической деятельности.

Ключевые слова: рамочные стандарты безопасности SAFE, международные профессиональные стандарты, подготовка, транзитные перевозки.

In the article (using the Ukrainian experience) there are considered problematic aspects of implementation of international standards in the field of international transit, which concern safety standards and world trade facilitation SAFE Framework of Standards as well as training and professional development of specialists in foreign economic activity.

Key words: SAFE Framework of Standards, international professional standards, training, international transit.

Сучасні процеси глобалізації, що відбуваються у світі, впливають на національних рівнях на інституційний розвиток і зумовлюють потребу в уніфікації і стандартизації процесів і процедур. Україна підписала Декларацію про наміри щодо впровадження Рамкових Стандартів безпеки i спрощення світової торгівлі, що дало змогу не лише використовувати міжнародні стандарти у розбудові національної митної системи, але й сприяло кращій погодженості національних пріоритетів у митній сфері з міжнародними стандартами і дозволило ефективніше захищати національні інтереси України у сфері розвитку міжнародної торгівлі й економічної співпраці передовсім через використання механізмів Всесвітньої митної організації (далі - ВМО) для модернізації митних служб, співпраці з приватним сектором економіки та імплементації стандартів.

Поставлена проблема універсальна на сучасному етапі інституційного розвитку для митних адміністрацій різних країн, брокерських фірм, фірм-перевізників. Їй присвячено увагу не лише вітчизняних [1-3], а й зарубіжних науковців [4-6]. Проте увага була зосереджена насамперед на питаннях підготовки та підвищення кваліфікації фахівців для митної служби, концепціям та механізмам підготовки державних службовців у сфері державного управління. Сьогодення ж дає виклики співпраці 3 приватним сектором економіки, участі державних структур в адаптації та імплементації міжнародних професійних стандартів в систему підготовки фахівців зовнішньоекономічної діяльності з приватного сектора.

Метою статmі є висвітлення (на прикладі українського досвіду) проблемні моменти адаптації та впровадження міжнародних норм і стандартів у сфері міжнародних транзитних перевезень, які стосуються як стандартів безпеки та спрощення світової торгівлі, так і підготовки та підвищення кваліфікації фахівців.

Наш аналіз підтвердив: важливим є розуміння процесів, що відбуваються. Теза перша: 32009 р. триває друга фаза нарощування потенціалу ВМО і митних служб, а саме — як реалізовувати міжнародні стандарти [1]. За прогнозами ВМО три роки триватиме процес розроблення практичних інструментів із упровадження модернізації, зокрема в аспекті спрощення митних процедур, стандартизації підготовки та підвищення кваліфікації фахівців у сфері зовнішньоекономічної діяльності (далі - ЗЕД) на міжнародному та національних рівнях держав-членів ВМО. Йдеться як про митників, так і про суб'єктів ЗЕД. ВМО планує надати своїм членам кращі практики та знання всіх митних служб 174 країн-членів ВМО, а також адресно їх експертну оцінку [4].

Теза друга: глобалізація економічних процесів зумовила актуалізацію проблем прискорення термінів вантажних перевезень, розвитку й ефективного використання транзитного потенціалу країн, формування єдиної світової транспортної мережі .

Через територію України проходить чотири міжнародних транспортних кордони. Географічне положення, розвинена транспортна мережа, наявність портів, що не замерзають повинні сприяти тому, щоб обсяги транзитних вантажопотоків через іiі територію збільшувалися [2]. Той факт, що Україна за своїм транзитним потенціалом посідає одне 3 перших місць у Свропі, визначає особливу значущість розроблення і проведення ефективної транспортної політики, спрямованої на усунення причин, що стримують розвиток транзиту вантажів в Україні, адаптацію і впровадження європейських стандартів у цій сфері. Провідну роль тут мають відіграватитакі чинники: створення відповідно до міжнародних стандартів національної мережі транспортних коридорів, прискорений розвиток транспортної інфраструктури, іiі інтегрування в транспортні системи Свропи та Азії, Балтійського і Чорноморського регіонів. 
Теза третя: у зв'язку з вищезазначеним політичним і економічним контекстом особливої ваги набуває питання підготовки фахівців для державного та приватного секторів, які могли б добре орієнтуватись у національному й європейському законодавстві, розв'язувати найбільш гострі питання, що виникають під час здійснення транзитних перевезень, зокрема, порядку застосування книжок МДП, карнетів А.Т.А. та ін. Розглянемо порушені питання більш докладно.

Успішне розв'язання завдань поліпшення організації транзитних перевезень без відповідного нормативно-правового забезпечення неможливо. Тут слід зазначити відставання головних управлінь Мінтрансу: у першу чергу, правового забезпечення та зовнішніх зв'язків. Неупорядкованими i тривалими залишаються процедура контрольно-перевірочних операцій та механізм оформлення документів на транзитні вантажі. Особливо це відноситься до автомобільних і контейнерних перевезень. Необхідно виконувати закони України, що регламентують транзит вантажів [11-14], навести належний порядок на кордоні.

Основні причини, що стримують розвиток транзиту вантажів в Україну, криються в невлаштованості системи контролю вантажів на кордоні, в оплаті високої вартості послуг, які надаються митними брокерами, контрольними службами і транспортними терміналами, в численних бюрократичних перешкодах під час оформлення транзитних перевезень, низькій швидкості доставки вантажів.

Для розуміння проблемних моментів адаптації та імплементації міжнародних норм і стандартів у сфері транзитних перевезень, зупинимось на проблемах, які виникають під час транзитного перевезення вантажів автомобільним транспортом, оскільки, зазначені вище проблемні питання застосування книжок МДП та карнетів А.Т.А безпосередньо стосуються й автомобільних перевезень. За статистичними даними автомобільний транспорт переважає у перевезенні пасажирів та вантажів на короткі дистанції “від дверей до дверей”. Автотранспорт має розвинену інфраструктуру та непогану базу технічного забезпечення. Якщо брати до уваги лише географічне положення України, то обсяги транзитних перевезень мали б постійно зростати, але цього не відбувається. Можна виокремити кілька проблем, які перешкоджають розширенню обсягів транзиту, а саме: поганий стан доріг України; митна інфраструктура; тарифна політика; відсутність транспортних терміналів; необхідність гармонізації законодавства України. Серед зазначених проблем Держмитслужба та фахівці Академії митної служби України можуть впливати на розв'язання деяких із них, а саме: митна інфраструктура; тарифна політика; транспортні термінали; гармонізація законодавства України.

Необхідно реалізувати низку першочергових заходів щодо адаптації законодавства України до міжнародних стандартів - aquis communautaire у сфері автомобільного транспорту. Хоч більшість сфер діяльності автомобільної транспортної галузі має вже досить розгалужену правову базу, ще $\epsilon$ низка важливих ділянок, які вимагають нормативно-правового врегулювання. Деякі галузі цієї сфери значною мірою відповідають праву $Є С$, а деякі лише частково. Відставання від європейських норм у розвитку автомобільних доріг передовсім автобанів (доріг найвищої категорії), зростає. Особливо гостро постає питання фінансування автомобільних доріг, залучення іноземних інвестицій. ЄС спрямовує значні кошти зі своїх спільних європейських фондів на розвиток транспортної інфраструктури на території Євросоюзу, про що свідчать директиви щодо спільного 3 країнамибенефіціантами фінансування автодоріг. Великі обсяги інвестицій вкладені й у розвиток інфраструктури держав-кандидатів до вступу у ЄС. Водночас, на Україну це фінансування не розповсюджується.

Незважаючи на те, що в Україні розроблено нормативно-правову базу щодо стягнення платні за проїзд автомобільними дорогами, платні дороги поки що відсутні. Транспортна політика СС як одну із генеральних ідей рекомендує введення платні за дороги. Уважається, що це забезпечить оцінку повних витрат суспільства на транспортну рухомість і дасть реальну можливість будувати та підтримувати автодороги у належному стані. Слід зважати також на те, що розміри плати за проїзд територією України іноземними транспортними засобами менший, ніж у Європі. Отже, тут теж слід приводити вітчизняну нормативно-правову базу у відповідність з європейською.

Інший приклад: вантажний автомобільний транспорт застосовує вільне ціноутворення, тоді як на пасажирському транспорті, особливо міському, тарифи залишаються фіксованими. Необхідно гармонізувати законодавство України щодо безмитного увезення транспортних засобів, для роботи найманого транспорту, для міжнародного перевезення пасажирів.

Статистична звітність автомобільного транспорту, наявна в Україні, за своєю ідеологією значно відрізняється від європейської, і зокрема Європейського Союзу, що також вимагає приведення ії до європейських вимог. Необхідне внесення змін до Правил перевезення небезпечних вантажів та Правил перевезення великовагових вантажів відповідно з конвенціями ЄЕК ООН та директивами ЄС.

Хоч нормативно-правова база з безпеки дорожнього руху в Україні достатньо розвинена, рівень безпеки дорожнього руху на порядок нижче, ніж у європейських країн. Українське законодавство не відповідає європейським вимогам щодо створення бази даних ДТП, ременів безпеки для дітей тощо.

Також необхідно зазначити, що задля підготовки до проведення фінальної частини чемпіонату світу з футболу Євро - 2012 вносяться певні зміни до митного законодавства, задля спрощення 
процедур митного оформлення товарів, зокрема й тих, які ввозяться тимчасово за карнетами А.Т.А. Такі зміни дозволять здійснювати митне оформлення міжнародних поштових та експрес відправлень, консолідованих вантажів, виставкових товарів, що ввозяться 3 використанням книжок (карнетів) А.Т.А., не тільки митними органами в пунктах пропуску через державний кордон України, але й у внутрішніх митницях. Це, в свою чергу, дасть змогу спростити здійснення митних процедур при митному оформленні зазначених товарів; оптимізувати порядок прийняття рішення про допуск деяких товарів до переміщення в режимі тимчасового ввезення (вивезення) та розширити перелік товарів, щодо яких такий порядок застосовується. Допущення таких товарів у режим тимчасового ввезення не потребуватиме попереднього розгляду та рішення митного органу.

Отже, дослідженням підтверджено наявність певної кількості проблемних законодавчих моментів, що потребують уніфікації з міжнародними нормами і стандартами [3], а реалізація всіх зазначених заходів безперечно потребує наявності висококваліфікованих фахівців в галузі транспортних технологій, економіки, права, митної справи.

Теза четверта: на сьогодні, коли ставка робиться на нарощування потенціалу митних служб, модернізація й уніфікація пов'язані з двома поняттями: зі стандартами діяльності (тобто митними, логістичними тощо) [7 - 8] і стандартами професійними (освітніми) [9 - 10].

Україна приєдналася, як було вже зазначено вище, до імплементації Рамкових стандартів безпеки і спрощення міжнародної торгівлі SAFE [7], які дають змогу здійснювати інтегроване управління ланцюгом постачань для всіх видів транспорту; до впровадження карнету А.Т.А. як інструменту ВMO з тимчасового ввезення товарів. Ми приєдналися й до імплементації Професійних стандартів ВMO [9].

Для того, щоб модернізація митних служб і приватного сектора економіки, що здійснює зовнішньоекономічну діяльність, була ефективною, митні навчальні заклади повинні впроваджувати два види стандартів: діяльності й освітні [5, с. 8]. Це означає, що необхідно мати уніфіковані вимоги до компетенцій митників; стандарти навчання і навчального матеріалу; майданчики для моделювання процесів відпрацювання управлінських і логістичних технологій, безпеки ланцюга постачання; для проведення навчання, спираючись на наукові напрацювання перспективних напрямків удосконалення зазначених технологій [3]. 3 іншого боку, виникає гостра потреба в підготовці фахівців у сфері міжнародних перевезень, брокерів, декларантів у контексті суміжних компетенцій: митника, перевізника й іншого суб'єкта ЗЕД - замовника. Таке завдання, у свою чергу, порушує питання питання розроблення уніфікованих професійних стандартів для фахівців у сфері міжнародних перевезень, чим вже займають професійні асоціації, наприклад, Міжнародна спілка автоперевізників (IRU).

Митна служба й академія завжди оперативно реагують на потреби у підготовці та перепідготовці фахівців, які безпосередньо здійснюють митну справу або надають послуги у сфері митної справи. Так, зокрема, 3 метою розв'язання проблемних питань із застосування карнетів А.Т.А. для ознайомлення 3 особливостями застосування митних режимів до товарів, які переміщуються через митний кордон $з$ використанням карнетів А.Т.А., митна служба провела семінари для митників за участю представників Всесвітньої Ради 3 питань карнетів А.Т.А., Торгово-промислових палат України і Російської Федерації. У межах навчальних дисциплін, які викладаються в академії, було впроваджено в дисципліну «Митне регулювання» модульний блок 3 питань використання книжок А.Т.А. під час переміщення товарів через митний кордон.

У результаті оперативного реагування на потреби міждержавного регіонального управління, потреби 3 підготовки та перепідготовки фахівців у галузі митної справи та зовнішньоекономічної діяльності, вдалося донести до суб'єктів ЗЕД і працівників митних органів основні переваги адаптації міжнародних норм щодо використання карнетів А.Т.А.: він дозволяє застосовувати скорочену процедуру тимчасового імпорту; до мінімуму обмежує кількість документів, необхідних для виконання формальностей, пов'язаних із тимчасовим ввезенням товарів; звільнює від необхідності внесення грошової застави або страховки в рахунок можливого мита. Це вигідно і безпосереднім користувачам і митним органам, торговим організаціям, бізнесменам, виробничим підприємствам та підприємствам сфери послуг, що бажають розширити свою діяльність за межі держави, проводять промоційно-рекламні акції тощо.

Не передбачається суттєвого скорочення попиту на фахівців відповідної підготовки навіть в умовах економічної кризи, оскільки одним із провідних заходів із подолання кризи визнано розвиток міжнародних відносин та розбудову митної інфраструктури на засадах змішаного (бюджетноприватного або концесійного) фінансування і залучення коштів міжнародних організацій у зв’язку 3 проведенням Свро-2012.

Під час дослідження виявлено загальні ключові проблеми підготовки фахівців для державного i приватного секторів у сфері зовнішньоекономічної діяльності, а саме: 1) різні національні системи і стандарти підготовки та підвищення кваліфікації; 2) необхідність уніфікації і стандартизації навчальних програм як основи для мобільності студентів / викладачів / робочої сили на глобальному ринку праці; «прозорості» та визнання дипломів; 3) необхідність актуалізації навчальних програм $і$ навчально-методичних матеріалів; 4) відповідність міжнародним професійним стандартам; 
5) нормативно-правове забезпечення легітимності та введення нових спеціальностей / професій; 6) необхідність для тих, хто навчається, оволодіння новими (суміжними) компетенціями; 7) відсутність у навчальних закладах полігонів моделювання процесів діяльності для відпрацювання технологічних процесів діяльності, наприклад, митних і логістичних процедур; 8) гарантована наявність місць практики, у тому числі міжнародної; 9) слабка підтримка донорськими організаціями двосторонніх і регіональних проектів партнерських митних ВН3, асоціацій, мереж; 10) організація роботи 3 громадськістю; 11) відсутність національного, регіонального, міжнародного банку даних висококваліфікованих викладачів (експертів-тренерів), що дозволило б об'єднати зусилля й зекономити ресурси ВНЗ.

Отже, на основі аналізу українського досвіду впровадження міжнародних норм і стандартів у сфері міжнародних транзитних перевезень виявлено проблемні моменти їх уніфікації та адаптації, які стосуються як стандартів безпеки та спрощення світової торгівлі, гармонізації законодавства України, так і підготовки та підвищення кваліфікації фахівців.

Процес уніфікації стандартів діяльності можливо здійснити лише через уніфікацію стандартів підготовки і підвищення кваліфікації. На наше переконання, до цієї роботи мають долучитися митні навчальні заклади, які готують не лише митників, а й фахівців для бізнесу. Зокрема, Академія митної служби України здійснює підготовку фахівців для потреб митної служби, а також фахівців для приватних установ, які здійснюють зовнішньоекономічну діяльність та надають послуги в сфері митної справи, наприклад, готуючи фахівців за спеціальностями «транспортні технології», «правознавство», «менеджмент ЗЕД», «міжнародна економіка» та ін. Отже, Академією закладається основа для формування потужного кадрового резерву високоякісних фахівців у галузі митної справи і зовнішньоекономічної діяльності, які здатні розв’язувати складні завдання щодо захисту економічних інтересів держави у сфері зовнішньоекономічної діяльності, в тому числі при здійсненні міжнародних транзитних перевезень.

\section{Література}

1. Пашко П. В. Митна безпека (теорія, методологія та практичні рекомендації): [монографія] / П. В. Пашко. - Одеса : АТ «ПЛАСКЕ», 2009. - 628 с. 2. Пісьмаченко Л. М. Державне управління зовнішньо-економічною діяльністю в Україні: регулювання та контроль: монографія / Л. М. Пісьмаченко. - Донецьк: «Юго-Восток, ЛТД», 2008. - 366 c. 3. Chentsov V. Improvement of foreign economic activity through implementation of WCO professional standards in curriculum of the Ukrainian Academy of Customs / V. Chentsov, O. Pavlenko, E. Kozlovski // Вісник Академії митної служби України. - № 1 (41). - Дніпропетровськ: АМСУ, 2009. - С. 38-51. 4. Hall A. Global Customs Capacity Building - the WCO Strategy / A. Hall // PICARD Conference, Shanghai, China. - 2008, Mai 14-16. - [Text file]. URL http://www.wcoomd.org/ event_picard 2008presentation.htm 5. Hodkinson P. The Challenge of Professionalism through Vocational Education and Training / P.Hodkinson, M.Issit (eds.). - Cassell, London, 1995. - P. 146 -156. 6. Kashubsky M. INCU Questionnaire Reponses: This is What We Know/ PICARD Conference, Shanghai, China. - 2008, Mai 14-16 / M.Kashubsky. - [Text file]. URL http://www.wcoomd.org/ event picard2008presentation.htm 7. WCO SAFE Framework of Standards. June 2007. - [Електронний ресурс]. Режим доступу: www.wcoomd.org. - Заголовок з екрану. 8. Customs Blueprints - Pathways to modern customs/European Commission. - Luxembourg: Office for Official Publications of the European communities. 2007. - 89 p. 9. Professional Standards. - Brussels, World Customs Organization. - 2008. - 46 p. 10. Програми сертифікації Центру розвитку професійних стандартів. - [Електронний ресурс]. - Режим доступу: http://www.uamdbe.org.ua/eng/news/?id=140. - Заголовок з екрану. 11. Об утверждении Порядка таможенного оформления товаров, которые перемещаются через таможенную границу с использованием книжек карнетов А.Т.А.// Приказ ГТСУ от 17.12.07 № 1058. [Електронний ресурс]. - Режим доступу: http://www.customs.gov.ua/. - Заголовок з екрану. 12. Митна конвенція про міжнародне перевезення вантажів із застосуванням книжки МДП (Конвенція МДП), 1975 р. [Електронний ресурс]. - Режим доступу: http://www.customs.gov.ua/. - Заголовок з екрану. 13. Порядок реалізації положень Митної конвенції про міжнародне перевезення вантажів із застосуванням книжки МДП // Офіційний вісник України від 04.01.2002 p., 51, c. 551, стаття 2325. 14. Про затвердження Порядку реалізації положень Митної конвенції про міжнародне перевезення вантажів із застосуванням книжки МДП / наказ ДМСУ від 21.11.01 № 755, [Електронний ресурс]. Режим доступу: http://www.customs.gov.ua/. - Заголовок з екрану. 